\title{
Sex Differential Influence of Acute Orally-administered Silver nanoparticles (Ag-NPs) on Some Biochemical Parameters in Kidney of Mice Mus musculus
}

\section{Heydrnejad MS* and Samani RJ}

Department of Biology, Faculty of Science, Shahrekord University, PO B 115, Shahrekord 88186, Iran

\begin{abstract}
Our data on the gender effect of Ag-NPs on animals are inconclusive with mixed results. This study, therefore aimed to clarify sex differential influence of acute orally-administered Ag-NPs on some biochemical parameters (Blood Urine Nitrogen (BUN), Creatinine ( $\mathrm{Cr}$ ), Sodium and Potassium) in kidney of mice Mus musculus. A group of BALB/c mice of about 9 weeks (weighting $27.2 \pm 3.0 \mathrm{~g}$ ) were randomly divided into three groups (each with two replications): Ag-NPs (2) and the control (1) groups, each with 9 mice. Almost equal numbers of male and female mice were used in this study. Once a day at the same time, a volume of 50 microliters from the nanosilver solution ( 20 and $50 \mathrm{ppm})$ was administered orally at a given time. The untreated (control) group received distilled water without Ag-NPs. Samplings $(n=9)$ were conducted on days 2,7 and 14 . The blood was obtained directly from heart using heparinized tubes. The serum was obtained by centrifugation of the whole blood at $3000 \mathrm{rpm}$ for $15 \mathrm{~min}$. Ag-NPs had potential to adversely affect the kidney functions in gender-dependent manner so that obvious kidney toxicity was found in female mice. This study suggests that female mice suffer more serious kidney toxicity than male mice when treated with Ag-NPs. Our findings build up necessary knowledge on Ag-NPs in vivo distribution and mechanisms responsible for Ag-NPs meditated toxicity to organisms. Further studies are required to elucidate in depth how Ag-NPs interact and affect cellular processes.
\end{abstract}

Keywords: Sex differential; Ag-NPs; Kidney; Mice

\section{Introduction}

Due to their antibacterial and their adaptability to biological systems, silver nanoparticles (Ag-NPs) have been considered as antibacterials made by human and could be used as additive instead of antibiotics [1,2]. Ag-NPs are groups of silver atoms ranging in size, in at least one dimension (typically spherical diameter), from 1 to $100 \mathrm{~nm}$ [3]. Ag-NPs are translocated into blood circulation and accumulated in some organs to cause renal toxicity or hepatotoxicity when administered through oral, inhalation or subcutaneously $[4,5]$. The current understanding about Ag-NPs tendency of tissue deposition and related adverse effects is limited [6,7], however, the oral toxicity of silver nanoparticles is of particular concern to ensure public and consumer health. Kidney could be a target because of its role in elimination of xenobiotics [8]. The kidneys regulate the amount of water and salts in the bodies by filtering the blood through millions of structures called nephrons. Blood urea nitrogen (BUN) is an indication of renal (kidney) health. Creatinine (Cr) (as a by-product of muscle) is also a waste product excreted through the kidneys. It is generally considered to be an accurate measurement of underlying kidney functions because it is less affected by diet, stress and dehydration. In fact, both BUN and $\mathrm{Cr}$ are two important factors to identify kidney function and level of these factors in blood serum is increased by renal damages [9]. Sodium $(\mathrm{Na})$ potassium $(\mathrm{K})$ and are two main electrolytes (salts), which are essential to the functioning of the body. The most common cause of high potassium is kidney failure. $\mathrm{Na}$ is also by far the major solute in extracellular fluids (ECF), so it effectively determines the osmolarity of extracellular fluids.

It must be noted that while the population exposed to silver nanoparticles continues to increase with ever new applications, silver nanoparticles remain a controversial research area as regards their toxicity to biological systems. In particular, the oral toxicity of silver nanoparticles is of particular concern to ensure public and consumer health.

In the male and female rats, target organs for silver nanoparticles are considered to be the lungs and liver [10]. Nevertheless, our data on the gender effect of Ag-NPs on animals are inconclusive with mixed results. For example, Ji et al. (2007b) found no significant changes in the hematology and blood biochemical values for both male and female rats. Likewise, Heydarnejad [3] found no gender-related tissue distribution of Ag-NPs in mice by oral administration. In contrast, inhalation studies show a sex-dependent accumulation of silver in rat kidney $[4,11]$. Thus, this study aimed to clarify sex differential influence of acute orally-administered Ag-NPs on some biochemical parameters in kidney of mice Mus musculus.

\section{Materials and Methods}

\section{Mice holding}

Animal test was performed with compliance of the local ethics committee. A group of $54 \mathrm{BALB} / \mathrm{c}$ mice of about 9 weeks (weighting $27.2 \pm 3.0 \mathrm{~g}$ ) were purchased from Medical Faculty of Shahrekord University and then transferred to the laboratory. The animals were housed in a single group and maintained on commercial pellet diet, given deionized water ad libitum and kept in plastic cages in a $20 \pm 2^{\circ} \mathrm{C}$, $50-70 \%$ relative humidity room with a 12-h light/dark cycle. After 2 weeks' acclimation, the mice were randomly divided into three groups (each with two replications): Ag-NPs (2) and the control (1) groups, each with 9 mice. The animals were kept fasting over night before

*Corresponding author: Heydarnejad MS, Shahrekord University, PO B 115 Shahrekord 88186, Iran, Tel: +983814424419; E-mail: msh@utas.edu.au

Received June 09, 2016; Accepted June 14, 2016; Published June 21, 2016

Citation: Heydrnejad MS, Samani RJ (2016) Sex Differential Influence of Acute Orally-administered Silver nanoparticles (Ag-NPs) on Some Biochemical Parameters in Kidney of Mice Mus musculus. J Nanomed Nanotechnol 7: 382 doi:10.4172/2157-7439.1000382

Copyright: @ 2016 Heydrnejad MS, et al. This is an open-access article distributed under the terms of the Creative Commons Attribution License, which permits unrestricted use, distribution, and reproduction in any medium, provided the original author and source are credited. 
Citation: Heydrnejad MS, Samani RJ (2016) Sex Differential Influence of Acute Orally-administered Silver nanoparticles (Ag-NPs) on Some Biochemical Parameters in Kidney of Mice Mus musculus. J Nanomed Nanotechnol 7: 382. doi:10.4172/2157-7439.1000382

Page 2 of 5

treatment. The mice were examined daily for infections. Almost equal numbers of male and female mice were used in this study.

\section{Preparation of Ag-NPs}

Silver nanoparticles (Ag-NPs) were purchased from Nano Pars Co., Iran with a purity of $95 \%$. The mean diameter of Ag-NPs averaged 40 $\mathrm{nm}$ (and ranged from 35 to $45 \mathrm{~nm}$ ), according to the manufacturer.

\section{Experiment}

Anesthesia for experimentation was achieved with an intramuscular injection of $10 \mathrm{ml}$ ketamine, $0.5 \mathrm{ml}$ acepromazine, $2 \mathrm{ml}$ Diazepam and about $0.5 \mathrm{ml}$ Xylazine solution at a dose of $50 \mathrm{mg} / \mathrm{Kg}$. Studies have indicated that nanosilver has a strong toxicological effect in the range concentrations of $10-50 \mathrm{ppm}$ [12]. Therefore, once a day at the same time, a volume of 50 microliters from the nanosilver solution (20 and 50 $\mathrm{ppm}$ ) was administered orally at a given time. The untreated (control) group received distilled water without Ag-NPs. Each group of mouse was housed separately. The experiment lasted for 14 days. Samplings $(n=9)$ were conducted on days 2, 7 and 14 . The blood was obtained directly from heart using heparinized tubes. The serum was obtained by centrifugation of the whole blood at $3000 \mathrm{rpm}$ for $15 \mathrm{~min}$. The serum was used to examine $\mathrm{Cr}, \mathrm{BUN}$, sodium and potassium in the control and treatments. Statistical analyses were performed using Student's paired t-test, one-way ANOVA, and Duncan post hoc test. A p value of 0.05 was considered significant. The results showed the average value \pm standard deviation.

\section{Results}

\section{Amount of BUN and $\mathrm{Cr}$}

The serum biochemical findings of measuring the amount of BUN and $\mathrm{Cr}$ in both sexes are shown in Figure 1. Administration of Ag-NPs to male and female mice produced alterations to the levels of $\mathrm{BUN}, \mathrm{Cr}$ and electrolytes, including sodium and potassium, relative to the control (Tables 1 and 2). Overall, serum BUN and Cr levels in female mice compared to the male mice decreased $10.57 \%$ and $11.11 \%$, respectively. No significant difference was found in the level of BUN between male and female mice with 20-ppm Ag-NPs, but it was significant when using a 50-ppm of Ag-NPs. Likewise, serum Cr level in female mice treated with 20-ppm (but not 50-ppm) of Ag-NPs significantly decreased. As $\mathrm{Cr}$ is a crucial marker for kidney function [13] a decrease in the level of $\mathrm{Cr}$ in the female mice indicates their kidneys may have been damaged.

\section{Amount of Sodium and Potassium Electrolytes}

Tables 3 and 4 show alterations to the levels of sodium and potassium electrolytes relative to the control. Although, a significant difference was found in the level of sodium between male and female mice with 20-ppm Ag-NPs at days 7 and 14 of the experiment but overall, serum sodium and potassium levels in female mice compared to the male mice increased $11.2 \%$ and $19.6 \%$, respectively. As high potassium (hyperkalemia) is the most common cause of kidney failure,

\begin{tabular}{|c|c|c|c|c|c|c|}
\hline \multirow{3}{*}{ Groups } & \multicolumn{3}{|c|}{$\mathrm{Cr}$} & \multicolumn{3}{|c|}{ BUN } \\
\hline & & Days & & & Days & \\
\hline & 2 & 7 & 14 & 2 & 7 & 14 \\
\hline Control & ${ }^{\mathrm{bc}} 0.05 \pm 0.23$ & ${ }^{\mathrm{bc}} 0.05 \pm 0.23$ & ${ }^{\mathrm{bc}} 0.05 \pm 0.23$ & ${ }^{\mathrm{ab}} 6.42 \pm 68.33$ & $\mathrm{ab}^{\mathrm{ab}} .42 \pm 68.33$ & ${ }^{\mathrm{ab}} 6.42 \pm 68.33$ \\
\hline 20-ppm & ${ }^{\mathrm{a}} 0.05 \pm 0.33$ & ${ }^{\mathrm{ab}} 0 \pm 0.3$ & ${ }^{\mathrm{abc}} 0.05 \pm 0.27$ & $8.50 \pm 62.33$ & $17.67 \pm 77.67$ & $16.50 \pm 61.67$ \\
\hline 50-ppm & ${ }^{a b} 0 \pm 0.3$ & $\mathrm{c} 0 \pm 0.2$ & ${ }^{\mathrm{bc}} 0.05 \pm 0.23$ & a21.96 \pm 86.67 & a7.02 \pm 85.67 & b8.66 \pm 61 \\
\hline
\end{tabular}

Table 1: Serum BUN and Cr levels in male mice following oral exposure to $20 \mathrm{ppm}$ and $50 \mathrm{ppm}$ concentrations of Ag-NPs. All data are the mean \pm SD. Means with the same letter are not significantly different (Duncan's test and $\mathrm{P}<0.05$ ).

\begin{tabular}{|c|c|c|c|c|c|c|}
\hline \multirow{3}{*}{ Groups } & \multicolumn{3}{|c|}{$\mathrm{Cr}$} & \multicolumn{3}{|c|}{ BUN } \\
\hline & & Days & & & Days & \\
\hline & 2 & 7 & 14 & 2 & 7 & 14 \\
\hline Control & ${ }^{\circ} 0 \pm 0.2$ & ${ }^{\circ} 0 \pm 0.2$ & ${ }^{\circ} 0 \pm 0.2$ & ab1.53 \pm 65.33 & ab $1.53 \pm 65.33$ & ab1.53 \pm 65.33 \\
\hline 20-ppm & ${ }^{\circ} 0 \pm 0.2$ & ${ }^{\mathrm{bc}} 0.05 \pm 0.23$ & ${ }^{\circ} 0 \pm 0.3$ & $\mathrm{a} 12.66 \pm 72.67$ & $\mathrm{a} 18.5 \pm 70.67$ & ${ }^{\mathrm{b}} 0.58 \pm 46.33$ \\
\hline 50-ppm & ${ }^{\mathrm{ab}} 0.05 \pm 0.27$ & ${ }^{\circ} 0 \pm 0.2$ & ${ }^{\circ} 0 \pm 0.2$ & ab $10.2 \pm 61.33$ & ab $20.0 \pm 62.33$ & ab9.64 \pm 63 \\
\hline
\end{tabular}

Table 2: Serum BUN and Cr levels in female mice following oral exposure to 20-ppm and 50-ppm concentrations of Ag-NPs. All data are the mean \pm SD. Means with the same letter are not significantly different (Duncan's test and $\mathrm{P}<0.05$ ).

\begin{tabular}{|c|c|c|c|c|c|c|}
\hline \multirow{3}{*}{ Groups } & \multicolumn{3}{|c|}{$\mathrm{Na}$} & \multicolumn{3}{|c|}{$K$} \\
\hline & & Days & & & Days & \\
\hline & 2 & 7 & 14 & 2 & 7 & 14 \\
\hline Control & b11.15 \pm 209.67 & b11.15 \pm 209.67 & b11.15 \pm 209.67 & ab3 \pm 13.09 & ab3 \pm 13.09 & ab3 \pm 13.09 \\
\hline 20-ppm & ${ }^{\mathrm{dc}} 8.88 \pm 206$ & ${ }^{d} 04 / 40 \pm 194$ & $\mathrm{a} 19.08 \pm 256$ & a $2.70 \pm 10.87$ & ${ }^{\circ} 0.18 \pm 7.55$ & ${ }^{\mathrm{b}} 0.11 \pm 8.44$ \\
\hline 50-ppm & ${ }^{\mathrm{abc}} 6.42 \pm 229.33$ & ${ }^{a b} 8.96 \pm 235.67$ & bcd $50.3 \pm 222.67$ & ${ }^{\circ} 64 / 0 \pm 9 / 7$ & ${ }^{\mathrm{a}} 0.46 \pm 13.41$ & ${ }^{\mathrm{b}} 0.35 \pm 9.02$ \\
\hline
\end{tabular}

Table 3: Serum Na and $\mathrm{K}$ levels in male mice following oral exposure to 20-ppm and 50-ppm concentrations of Ag-NPs. All data are the mean \pm SD. Means with the same letter are not significantly different (Duncan's test and $P<0.05$ ).

\begin{tabular}{|c|c|c|c|c|c|c|}
\hline \multirow{3}{*}{ Groups } & \multicolumn{3}{|c|}{$\mathrm{Na}$} & \multicolumn{3}{|c|}{$\mathbf{K}$} \\
\hline & & Days & & & Days & \\
\hline & 2 & 7 & 14 & 2 & 7 & 14 \\
\hline Control & ${ }^{\mathrm{b}} 3.05 \pm 227.67$ & b3.05 \pm 227.67 & b3.05 \pm 227.67 & ${ }^{\mathrm{a}} 0.60 \pm 18.2$ & ${ }^{\mathrm{a}} 0.60 \pm 18.2$ & ${ }^{\mathrm{a}} 0.60 \pm 18.2$ \\
\hline 20-ppm & ${ }^{\mathrm{b}} 05 / 3 \pm 67227$ & a $21 \pm 243$ & ab $2.52 \pm 227.67$ & ${ }^{c} 3.40 \pm 8.07$ & ${ }^{\circ} 0.82 \pm 9.77$ & ${ }^{c} 1.59 \pm 7.86$ \\
\hline 50-ppm & b19/14216.67 \pm & ab9.71 \pm 228.67 & ${ }^{\mathrm{b}} 6.51 \pm 219.33$ & $\mathrm{c} 1.06 \pm 7.55$ & $2.60 \pm 15.32$ & ${ }^{\circ} 0.45 \pm 7.79$ \\
\hline
\end{tabular}

Table 4: Serum Na and K levels in female mice following oral exposure to 20-ppm and 50-ppm concentrations of Ag-NPs. All data are the mean \pm SD. Means with the same letter are not significantly different (Duncan's test and $\mathrm{P}<0.05$ ). 
Citation: Heydrnejad MS, Samani RJ (2016) Sex Differential Influence of Acute Orally-administered Silver nanoparticles (Ag-NPs) on Some Biochemical Parameters in Kidney of Mice Mus musculus. J Nanomed Nanotechnol 7: 382. doi:10.4172/2157-7439.1000382

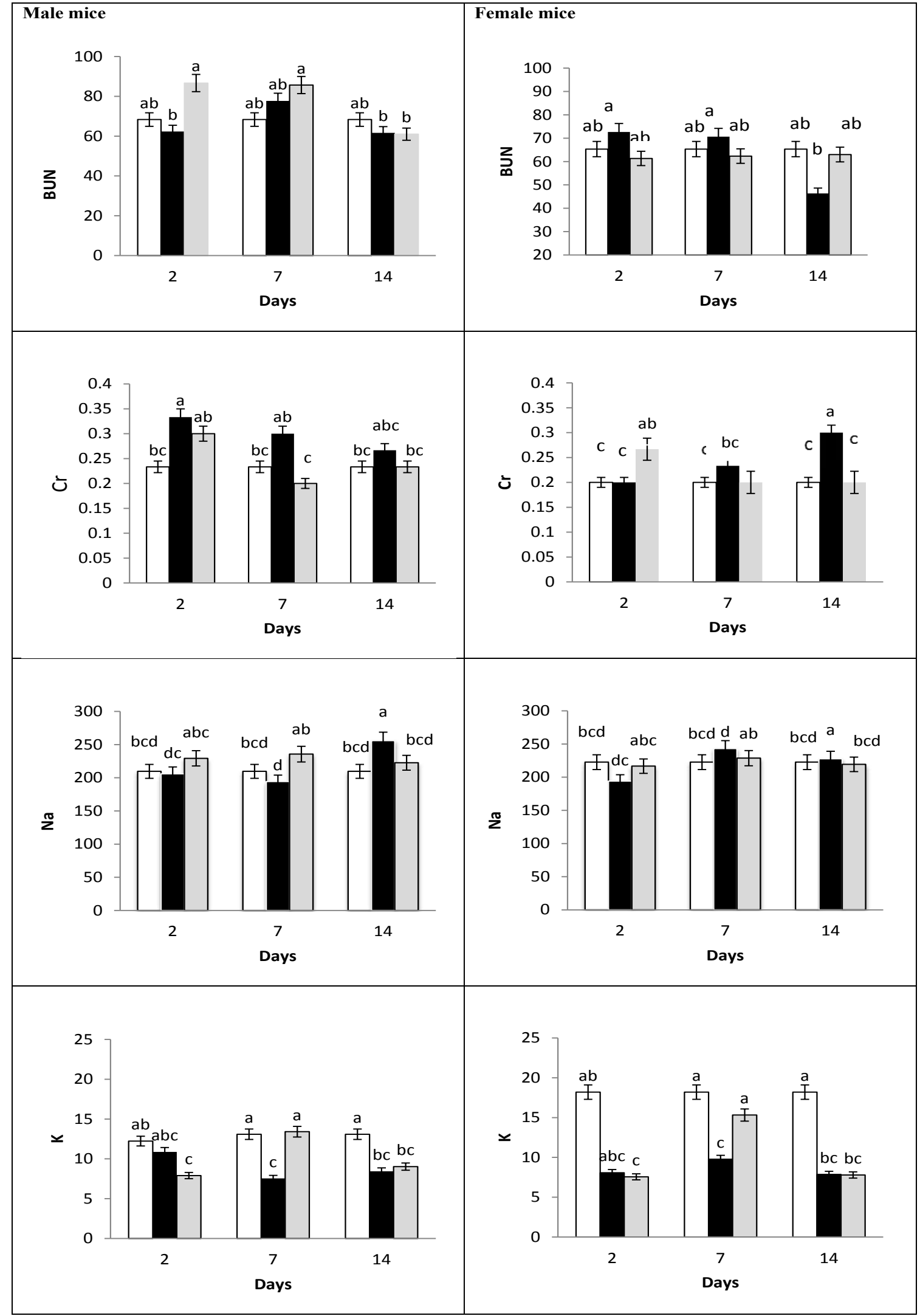

Figure 1: Biochemical results from the effects of Ag-NPs on levels of mice blood urine nitrogen (BUN), creatinine (Cr), sodium (Na) and potassium (K) following oral exposure to 20 -ppm and $50-p p m$ concentrations of Ag-NPs in male (left) and female (right). Data are presented as mean \pm SEM. Means with the same letter are not significantly different (Duncan's test and P<0.05). In each series, first column (white) denotes control, $2^{\text {nd }}$ column (dark) 20-ppm Ag-NPs and $3^{\text {rd }}$ column (gray) 50-ppm Ag-NPs. 
Citation: Heydrnejad MS, Samani RJ (2016) Sex Differential Influence of Acute Orally-administered Silver nanoparticles (Ag-NPs) on Some Biochemical Parameters in Kidney of Mice Mus musculus. J Nanomed Nanotechnol 7: 382. doi:10.4172/2157-7439.1000382

Page 4 of 5

it appears that female mice are more likely to be affected by toxic effects of Ag-NPs than male mice.

\section{Discussion}

This study investigated the sex differential influence of acute orallyadministered silver nanoparticles (Ag-NPs) on some biochemical parameters in kidney of mice Mus musculus. Ag-NPs had potential to adversely affect the kidney functions in gender-dependent manner so that obvious kidney toxicity was found in female mice. This was indicated by a significant decrease of serum $\mathrm{Cr}$ level and hyperkalemia in the female mice. Overall, the study suggests that female mice suffer more serious kidney toxicity than male mice when treated with Ag-NPs.

Despite their widespread application, comprehensive biologic and toxicologic information of Ag-NPs is lacking. Current in vitro studies have shown that Ag-NPs have potential to induce toxicity in cells derived from a variety of organs [14]. In fact, Ag-NPs are widely used as bactericidal agents in consumer products, but their potential toxicity remain poorly understood.

It has been demonstrated that sex differences are an important aspect in pharmacokinetic and pharmacodynamics research [15]. Changes in plasma protein and hormonal levels are obvious significant sex differences which may occur during the menstrual cycle [16]. This leads to different physiological responses during blood circulation for males and females, due to the possible effects on interactions between blood plasma and nanaoparticles (Chen et al., 2013). The current study showed that sex differences can lead to significant differences in the toxicity of Ag-NPs. This was indicated by more alterations of BUN and $\mathrm{Cr}$ levels in female than male mice. $\mathrm{Cr}$ is a break-down product of creatine phosphate in muscle, and is usually passed into the bloodstream and then out in urine. Measuring serum BUN and $\mathrm{Cr}$ is the most commonly used indicator of renal function [9]. A low blood levels of BUN and $\mathrm{Cr}$ in the female mice of current study indicate that the kidneys may not be functioning properly and that Ag-NPs caused more significant kidney damage in female mice than male mice. Furthermore, GFR (glomerular filtration rate) as the best overall biomarker of kidney function in mice is determined by assessing serum $\mathrm{Cr}$. Therefore, sex differences result in possible toxicological differences (Chen et al.).

A gender-related effects of Ag-NPs in the kidneys of the current study is consistent in the results from other inhalation studies. For example, Kim [9] and Song [17] in Sprague-Dawley rats found a gender-related difference in the accumulation of silver in the kidneys, with a twofold increase in the female kidneys when compared with the male kidneys. In addition, they found some significant dose-dependent changes in the alkaline phsophatase and cholesterol values in either the male or female rats.

The evaluation of body fluids in tissues and serum plays a key role in assault on organs and to a reasonable extent, toxicity assessment [18]. The observed elevation in the level of sodium in Ag-NPs treated female mice of the current study suggests a probable effect on the sodium/potassium pump. The pump maintains constancy in the concentration of sodium or potassium electrolytes in extracellular fluids [19-23]. Likewise, a raised level of serum potassium following Ag-NPs administration to female mice may signal early kidney stress. Nevertheless, this finding is in contrast with Yong who had previously reported nonsignificant alterations to the levels of serum potassium following Ag-NPs administration to female rat. The origin of the difference in effects measurements remains to be resolved, however it has been suggested that most of the xenobiotics that are excreted from the organism are eliminated more rapidly by males than by female animals [20-24]. This may explain more toxicity of Ag-NPs on female mice than male mice. Overall, these findings reveal that Ag-NPs had a more pronounced toxic effect on the function of female rather than male mice kidney.

In conclusion, our findings build up necessary knowledge on $\mathrm{Ag}-\mathrm{NPs}$ in vivo distribution and mechanisms responsible for $\mathrm{Ag}$ NPs meditated toxicity to organisms. Further studies are required to elucidate in depth how Ag-NPs interact and affect cellular processes.

\section{Acknowledgments}

The authors would like to thank Shahrekord University for allowing us to perform this study.

\section{Ethical Statements}

The study was conducted on the "Compliance with Ethical Standards".

\section{References}

1. Mritunjai S, Singh S (2008) Nanotechnology in medicine and antibacterial effect of silver nano particles. J. Nanomat. Biostruc 3: 115-122.

2. Franci G, Falanga A, Galdiero S (2015) Silver nanoparticles as potential antibacterial agents. Molecules 20: 8856-8874

3. Heydrnejad MS, Samani RJ, Aghaeivanda S (2015) Toxic Effects of Silve Nanoparticles on Liver and Some Hematological Parameters in Male and Female Mice (Mus musculus). Biol Trace Elem Res 165: 153-158.

4. Kim S, Choi JE, Choi J, Chung KH, Park K, et al. (2009) Oxidative stressdependent toxicity of silver nanoparticles in human hepatoma cells. Toxicol In Vitro 23: 1076-1084

5. Tang J, Xiong L, Wang S, Wang J, Liu L, et al. (2009) Distribution, translocation and accumulation of silver nanoparticles in rats. J Nanosci Nanotechnol 9: 4924-4932.

6. Herzog F, Clift MJ, Piccapietra F, Behra R, Schmid O, et al. (2013) Exposure of silver-nanoparticles and silver-ions to lung cells in vitro at the air-liquid interface. Part Fibre Toxicol 10: 11.

7. Wang Z, Qu G, Su L, Wang L (2013) Evaluation of the Biological Fate and the Transport through Biological Barriers of Nanosilver in Mice. Current Pharmaceutical Design 19: 1-5.

8. Passagne I, Morille M, Rousset M, Pujalté I, L'azou B (2012) Implication of oxidative stress in size-dependent toxicity of silica nanoparticles in kidney cells. Toxicology 299: 112-124.

9. Dayani M, Fathpour H, Naghsh N (2014) The effect of silver nanoparticles and thioacetamide on blood urea nitrogen and creatinine in male laboratory mice. Inter J Biosc 1: 139-142.

10. Sung JH, Ji JH, Park JD, Yoon JU, Kim DS, et al. (2009) Subchronic inhalation toxicity of silver nanoparticles. Toxicol Sci 108: 452-461.

11. Song KS, Sung JH, Ji JH, Lee JH, Lee JS, et al. (2013) Recovery from silvernanoparticle-exposure-induced lung inflammation and lung function changes in Sprague Dawley rats. Nanotoxicol 7: 169-180.

12. Greulich C, Braun D, Peetsch A, Diendorf J (2012) The toxic effect of silver ions and silver nanoparticles towards bacteria and human cells occurs in the same concentration range. RSC Adv 2: 6981-6987.

13. Kim YS, Kim JS, Cho HS, Rha DS, Kim JM, et al. (2008) Twenty-eight-day oral toxicity, genotoxicity, and gender-related tissue distribution of silver nanoparticles in Sprague-Dawley rats. Inhal Toxicol 20: 575-583.

14. Takahashi N, Boysen G, Li F, Li Y, Swenberg JA (2007) Tandem mass spectrometry measurements of creatinine in mouse plasma and urine for determining Ahamed glomerular filtration rate. Kidney Int 71: 266-271.

15. Beierle I, Meibohm B, Derendorf H (1999) Gender differences in pharmacokinetics and pharmacodynamics. Int J Clin Pharmacol Ther 37: 529-547.

16. Gleiter CH, Gundert-Remy U (1996) Gender differences in pharmacokinetics. Eur J Drug Metab Pharmacokinet 21: 123-128.

17. Kim YS, Song MY, Park JD, Song KS, Ryu HR, et al. (2010) Subchronic oral toxicity of silver nanoparticles. Part Fibre Toxicol 7: 20

18. Adeyemi OS, Akanji MA (2011) Biochemical changes in the kidney and live of rats following administration of ethanolic extract of Psidium guajava leaves. Hum Exp Toxicol 30: 1266-1274. 
Citation: Heydrnejad MS, Samani RJ (2016) Sex Differential Influence of Acute Orally-administered Silver nanoparticles (Ag-NPs) on Some Biochemical Parameters in Kidney of Mice Mus musculus. J Nanomed Nanotechnol 7: 382. doi:10.4172/2157-7439.1000382

Page 5 of 5

19. Adeyemi OS, Adewumi I, Faniyan TO (2015) Silver nanoparticles influenced rat serum metabolites and tissue morphology. J Basic Clin Physiol Pharmacol 26: 355-361

20. Reyes JL, Meléndez E, Alegría A, Jaramillo-Juárez F (1998) Influence of sex differences on the renal secretion of organic anions. Endocrinology 139: 15811587.

21. Furchner JE, Richmond CR, Drake GA (1968) Comparative metabolism of radionuclides in mammals-IV. Retention of silver- $110 \mathrm{~m}$ in the mouse, rat, monkey, and dog. Health Phys 15: 505-514.
22. Ji JH, Jung JH, Kim SS, Yoon JU, Park JD, et al. (2007) Twenty-eight-day inhalation toxicity study of silver nanoparticles in Sprague-Dawley rats. Inhal Toxicol 19: 857-871.

23. Kvitek L, Vanickova M, Panacek A (2009) Initial Study on the Toxicity of Silver Nanoparticles (NPs) against Paramecium caudatum. J Phys Chem C 113: 4296-4300.

24. Taylor E H (1989) Clinical Chemistry. New York, John Wiley and Sons, pp: 58-62. 